\title{
NOTES ON THE SEX OF THE GAMETOPHYTE OF ONOCLEA STRUTHIOPTERIS
}

\author{
David M. Mottier
}

During the past two or three years the writer has been collecting data from a study upon the gametophyte of Onoclea Struthiopteris with reference especially to the dioecious character of the prothallia, and while this study is in no way completed, it has been deemed advisable to make public some of the facts observed, inasmuch as the data obtained supplement those set forth in a very interesting paper, appearing in a recent number of this journal, by Miss WuIsT. ${ }^{x}$

The impression is general that the prothallia of Onoclea Struthiopteris are dioecious, ${ }^{2}$ and although this is generally true, it is not strictly so, as bisexual prothallia may readily be found under ordinary and perhaps optimum cultural conditions. In $\mathrm{I}_{907}$, in an address before the Indiana Academy of Science, ${ }^{3}$ I made the following statement:

The writer has recently begun the study of a fern, whose prothallia have been reported as strictly dioecious, and if the spores of the same are well nourished, female prothallia will predominate, while with poor nourishment the vast majority of spores will give rise to male gametophytes. An examination of cultures grown under favorable conditions for laboratory use, in which the spores were sown thickly, showed that certain spores produced strictly male plants, others female, and still others bisexual prothallia. A small number of spores were isolated and grown under similar and very favorable conditions, with similar results. The pure males were almost equal in number to those bearing the female organs, while the bisexual plants were few, being about 4 per cent of the whole number. The foregoing results seem to lend encouragement to the view that environmental conditions may have much less to do with the development of male and female prothallia than had hitherto been supposed. The very brief study showed clearly that in the fern in question

${ }^{\mathrm{I}}$ WUIST, Elizabeth DoRothy, The physiological conditions for the development of monoecious prothallia in Onoclea Struthiopteris. Bот. GAZETTE 49:216-219. I910.

2 Campbell, D. H., Mosses and ferns. Edition 2, p. 3r4. I905.

3 Motrier, D. M., History and control of sex. Proc. Ind. Acad. Sci. I907.pp. 44-45. 
there is a great mortality among the spores, which, as can be readily seen, vary greatly in size. Among the first things to establish in this and similar cases, is whether mortality is greatest among the smaller or larger spores, and whether the prothallia springing from the smaller spores tend to remain small and produce only antheridia, while the larger female plants arise only from the larger spores, and so on.

The fern in question was Onoclea Struthiopteris, although the name of the plant was not stated in the address in question.

Miss Wuist ( $o p$. cit. p. $2 \mathrm{I} 7)$ states that about I per cent of the prothallia of soil cultures were monoecious. This estimate seems to me to be much too low, inasmuch as an examination of a larger number of prothallia, since the publication of the paragraph just quoted, showed that about I2 per cent were monoecious. The prothallia from which this estimate was made were grown upon soil under good cultural conditions. The plants, although grown thickly, were vigorous, normal in every way, and in fact the cultures seemed to leave nothing to be desired. The monoecious prothallia were as a rule young, bearing one to several archegonia, and were $1.5-3 \mathrm{~mm}$. in diameter. Antheridia were very rarely found on older and larger prothallia, although little attention was paid to exact size and measurement. The antheridia were as a rule upon the ventral side, among or near the rhizoids, hence upon the older tissue; very rarely did they appear at the margin of the prothallium. In one case an antheridium was found upon the archegonial meristem.

In determining whether prothallia were monoecious, I did not rely at all upon an examination of fresh material, but all plants were carefully fixed, stained in toto with borax carmine, cleared, and examined in clove oil or balsam. In this way a single small antheridium could easily be found upon a prothallium, and cases were not infrequent of a single antheridium appearing inconspicuously among the rhizoids. It has been my experience that one or two immature antheridia among the rhizoids are easily overlooked when the plants are examined alive. In material thus stained and cleared, one may also more readily and accurately detect very small male plants adhering among the rhizoids of the larger prothallia bearing archegonia.

In order to ascertain whether crowding was in any way respon- 
sible for the sex of the gametophytes, cultures were made by sowing spores thinly upon the soil and keeping the cultures under the most favorable conditions available. One such culture may be mentioned in detail. In this 207 spores were sown and 150 prothallia harvested. Of these 78 were pure males, while 72 bore archegonia, and of the latter ro per cent were monoecious. Cultures were also made to determine, if possible, whether the spores of any given sporangium were male or female, as has been reported for certain liverworts. In this set of experiments the spores of individual sporangia were sown upon earth in separate dishes, with results similar to those from spores sown from many sporangia, that is, both male and female prothallia were grown; of the female, those bearing archegonia, some few were bisexual. Such experiments show conclusively that sporangia do not bear spores giving rise exclusively to male or female prothallia, and the fact that prothallia are bisexual is proof that no sex-differentiating chromosome is present in this fern.

No effort has been made up to this time by the writer to induce the development of antheridia upon "female" prothallia. Interesting experiments along this line have been carried out by Miss WUIST, as mentioned in the foregoing, with the following results: monoecious prothallia were obtained by transferring the plants from distilled water to Knop's solution, in which they were further cultivated; by transferring "female" prothallia from soil to a nutritive solution, and by transferring from one nutritive solution to another.

These experiments indicate that gametophytes bearing archegonia only may be induced to develop antheridia as a response to environmental conditions. Knowing that dioecism has not been completely established, these results, though important, are not surprising. They do not show a very far-reaching influence of environmental factors in regard to the regulation of the development of sex cells; for I have frequently observed in older cultures, that is, about five months after sowing, that certain "female" prothallia, in which an egg failed to be fertilized, developed from the oldest parts numerous small lobes which give that end of the prothallium a finely fringed appearance, and upon these lobes 
numerous antheridia were produced. Such prothallia were well nourished, with a deep-green color, and continued to develop the archegonial meristem, which produced continuously numerous archegonia. The specimens before me at this writing are $5^{-6} \mathrm{~mm}$. in length. As stated, the antheridial lobes were confined generally to the posterior or older parts of the prothallia, but they may extend a short distance forward along the margins. Antheridia were not observed, except in very rare cases, upon the archegonial meristem.

After all, the fact that archegonial plants may develop organs of the opposite sex, either normally or in response to conditions controlled in a measure by the experimenter, may readily find a satisfactory explanation, but the case may be different in regard to the prothallium that produces only antheridia. If purely male prothallia of Onoclea Struthiopteris are merely those that do not become large enough, because of nourishment, to bear archegonia, why is it that these pure males cannot be made to grow large enough to develop the female organ? The writer knows of no case on record in which this has been done. If the male plants could be made to develop the archegonial meristem and its archegonia, then it may be said that the environment (which of coures means chiefly nutrition) controls sex to that degree. The writer has not been able to believe that male prothallia of the fern in question are merely those that do not become large enough to bear archegonia, but that certain spores are predetermined to develop into purely antheridial plants, and others into those capable of forming archegonia. If there were a sex-determining chromosome, then one half of the spores would be male and one half female, but as the "female" prothallia bear occasionally antheridia, it cannot be said that a sex-determining chromosome is present. The explanation which we are able to give at present is that in certain spores the male tendency is dominant, while in others it is the female, but such statements mean little at present.

In a foregoing paragraph reference was made to the mortality among the spores, and to the variation in their size and apparent vigor. Some are larger and more healthy looking than others, and, as in many plants, many spores seem to be and doubtless are 
abortive. It was thought at one time in this study that the smaller spores were the ones that produced the purely antheridial prothallia, but sowings were made by selecting, in so far as possible, the more vigorous spores (an extremely tedious process), but the results did not bear out the expectation. Owing to the difficulties of selecting individual spores, it is not maintained that the lastnamed experiment is of any great value, at least the writer does not lay any stress upon the results. It seems reasonable that a larger percentage of the smaller spores, that is, those which show less chlorophyll and which germinate less readily; would fail to grow than in the case of the larger ones, so that the possibility of the smaller and abortive-looking spores producing chiefly male prothallia is not excluded. However, on this point the writer can make no definite assertions.

The foregoing statements may be summarized as follows:

I. The spores of Onoclea Struthiopteris when grown upon earth, under optimum cultural conditions, produce regularly three kinds of prothallia: small plants bearing only antheridia, the so-called male gametophytes; larger prothallia bearing only archegonia, the female gametophytes; and those bearing both archegonia and antheridia, the bisexual or monoecious prothallia.

2. Archegonial prothallia, which continue growth without bearing a sporophyte, sometimes develop numerous small lobes from the older portions, upon which numerous antheridia appear.

3. The gametophyte, therefore, is not strictly dioecious, and there is in all probability no sex-determining chromosome.

4. It is highly probable that the development of purely male or female gametophytes is not dependent upon conditions of nutrition, but that the sexual tendency is predetermined in the spore. Environmental conditions, or the failure of an egg to give rise to a sporophyte, owing to a lack of fecundation, may induce the development of antheridia upon archegonial plants, which continue their growth for some months.

5. Pure males result, in so far as is known, under good cultural conditions from the dominance of the male tendency in the spore over the female tendency. 


\section{$2 \mathrm{BHL}$ Biodiversity Heritage Library}

Mottier, David M . 1910. "Notes on the Sex of the Gametophyte of Onoclea struthiopteris." Botanical gazette 50(3), 209-213.

https://doi.org/10.1086/330332.

View This Item Online: https://www.biodiversitylibrary.org/item/109461

DOI: https://doi.org/10.1086/330332

Permalink: https://www.biodiversitylibrary.org/partpdf/224443

\section{Holding Institution}

Missouri Botanical Garden, Peter H. Raven Library

\section{Sponsored by}

Missouri Botanical Garden

\section{Copyright \& Reuse}

Copyright Status: Public domain. The BHL considers that this work is no longer under copyright protection.

This document was created from content at the Biodiversity Heritage Library, the world's largest open access digital library for biodiversity literature and archives. Visit BHL at https://www.biodiversitylibrary.org. 